\title{
Publikacje Profesora Adama Lityńskiego za lata 2015-2019*
}

\section{5}

1. [Wspólnie z Barbarą Czapik-Lityńską]: Kazneno pravo u poljičkom Statutu [Prawo karne w Statucie Polic. Zagadnienia wybrane]. U Spomenica u čast Nedjeljku Kujundžiću [Księga pamiątkowa Profesora Nedjeljko Kujundižća]. Ur. M. Nosić. Rijeka [Chorwacja], s. 486-499.

2. Z dziejów sąów tajnych $w$ Warszawie (1950-1954): o niektórych ludziach i sprawach uwag kilka. W: Historia testis temporum, lux veritatis, vita memoriae, nuntia vetustatis. Księga jubileuszowa dedykowana Profesorowi Włodzimierzowi Kaczorowskiemu. Red. E. Kozerska, M. Maciejewski, P. Stec. Opole, s. 627-644.

3. Prawo karne w okresie PKWN: wahania i decyzje. „Roczniki Administracji i Prawa", R. 15, z. 1, s. 61-79.

4. [Wspólnie z Marią Jabłońską]: „Być Polakiem w Związku Sowieckim w 1938 roku, to mniej więcej to samo, co być Żydem w III Rzeszy”. W zwiąku z książka Nikołaja Iwanowa: „Zapomniane ludobójstwo. Polacy w państwie Stalina. „Operacja polska «1937-1938”. Kraków: Społeczny Instytut Wydawniczy „Znak”, 2014, 445 s. [Artykuł recenzyjny]. „Z Dziejów Prawa”, T. 8 (16), s. 171-194.

5. Mirosław Szumiło: „Roman Zambrowski 1909-1977. Studium z dziejów elity komunistycznej w Polsce”, wyd. IPN, Warszawa 2014, ss. 527 + ilustracje. [Rec.]. „Czasopismo Prawno-Historyczne”, z. 2, s. 348-354.

6. Piotr Szopa: „W imieniu Rzeczypospolitej...”. Wymiar sprawiedliwości Polskiego Państwa Podziemnego na terenie Podokręgu AK Rzeszów, wyd. IPN O/Rzeszów, Rzeszów 2014, ss. 616. [Rec.]. „Czasopismo Prawno-Historyczne”, z. 2, s. 354-359.

* Wykazy wcześniejszych publikacji Profesora Adama Lityńskiego zamieszczono w: O prawie i jego dziejach księgi dwie. Studia ofiarowane Profesorowi Adamowi Lityńskiemu w czterdziestopięciolecie pracy naukowej i siedemdziesięciolecie urodzin. Ks. I. Białystok-Katowice 2010, s. 29-48 (za lata 1965-2010); „Miscellanea Historico-Iuridica” 2015, T. 14, z. 1, s. $9-13$ (za lata $2010-2015$ ). 
7. Karol Siemaszko: „W trudnym okresie odbudowy państwa”. Tak zwany maty kodeks karny w świetle orzecznictwa Sadu Okregowego w Krakowie w latach 19461950. Wyd. IPN. Warszawa 2015, ss. 351. [Rec.]. „Krakowskie Studia z Historii Państwa i Prawa" T. 8(4), s. 447-452.

8. [Wspólnie z Marianem Mikołajczykiem]: Marian Lech Klementowski (19432023). [Wspomnienie]. „Z Dziejów Prawa” 2014, T. 7(15), s. 297-300.

9. Wspomnienia zawodowe Adama Lityńskiego. „Czasopismo Prawno-Historyczne”, T. 67 , z. 1 , s. $357-389$.

10. Prawo $i$ sady $w$ totalitaryzmie. Polska 1944-1956. W: Systemy reprezentacji $i$ parlamentaryzm $w$ Europie Środkowej $w$ rozwoju historycznym. Red. A. Barciak. Katowice-Zabrze 2016, s. 191-212.

11. Rewolucji rosyjskiej rok pierwszy. Wybrane zagadnienia prawa karnego. W: Nil nisi veritas. Ksiega dedykowana Profesorowi Jackowi Matuszewskiemu. Red. M. Głuszak, D. Wiśniewska-Jóźwiak. Łódź, s. 473-489.

12. Lex retro agit $w$ ustawodawstwie karnym Polski po II wojnie. W: Wokót problematyki stosowania prawa. Red. D. Fleszer, A. Rogacka-Łukasik. Sosnowiec, s. $306-321$.

13. O sądach wojskowych dla osób cywilnych w Polsce (1946). W: Od prawa przeszłego do współczesnego. Księga jubileuszowa dedykowana Profesorowi Wojciechowi Witkowskiemu. „Studia Iuridica Lublinensia”, Vol. 25, nr 3, s. 523—541.

14. Narody w Rosji 1917 roku. Skutki rewolucji. Uwagi na kanwie ksiązki: Richard Pipes, ,Czerwone imperium. Powstanie Zwiąku Sowieckiego”. Ttum. W. Jeżewski. Wyd. Magnum. Warszawa 2015, ss. 363. [Artykuł recenzyjny]. „Czasopismo Prawno-Historyczne", T. 68 , z. 1, s. 217-242.

15. Ukraina od Rządu Tymczasowego do zamachu bolszewickiego. W setna rocznice rewolucji 1917. „Roczniki Administracji i Prawa”, T. 16, z. 2, s. 83-102.

16. Karol Łopatecki, „Organizacja, prawo $i$ dyscyplina $w$ polskim i litewskim pospolitym ruszeniu (do połowy XVII wieku)”. Białystok 2013, ss. 660. [Rec.]. W: „Roczniki Administracji i Prawa", R. 16, z. 1, s. 359-363.

17. Aneta Giedrewicz-Niewińska: „Projekt kodeksu pracy z 1949 r.”. Wydawnictwo Napoleon V. Oświęcim 2015, ss. 218. [Rec.]. „Roczniki Administracji i Prawa”, R. 16, z. 1, s. $355-358$.

18. Marian Lech Klementowski (1943-2013). [Wspomnienie pośmiertne; przedruk z „Roczników Administracji i Prawa” 2013, T. 13]. „Rocznik Historyczno-Archiwalny", s. $315-317$.

19. Wojciech Szczygielski, ,,Sejm Wielki (1788-1792). Studium z dziejów łagodnej rewolucji”. Wyd. Lódzkie Towarzystwo Naukowe. Łódź 2015, ss. 198. „Roczniki Administracji i Prawa", R. 16, z. 1, s. 364-365. 
20. Tadeusz Maciejewski: „The History of Polish Legal System from the $10^{\text {th }}$ to the $20^{\text {th }}$ century”. „Roczniki Administracji i Prawa”, R. 16, z. 2, s. 489-490.

21. Prawo Rosji i ZSRR 1917-1991, czyli historia wszechzwiazkowego komunistycznego prawa (bolszewików). Krótki kurs. Wyd. 3. Warszawa, ss. $431+34$ numerowane cyframi arabskimi.

22. [Wspólnie z Wiktorem Hołubką]: Na gruzach imperium. Ukraina po upadku cesarstwa rosyjskiego: od rewolucji lutowej 1917 do traktatu brzeskiego 1918. „Czasopismo Prawno-Historyczne", T. 69, z. 1, s. 83-129.

23. [Wspólnie z Wiktorem Hołubką]: Zagadnienie państwowości białoruskiej w latach 1917-1920. W setna rocznice rewolucji 1917. „Roczniki Administracji i Prawa", [zeszyt specjalny], s. 115-137.

24. W cieniu zbrodni i występków. O ostatniej kodyfikacji prawa wykroczeń w Polsce. $W$ zwiazku z książka Marcina Łysko „Prace nad kodyfikacja materialnego prawa wykroczeń w Polsce Ludowej (1960-1971)" [Wyd. Temida 2, Białystok 2016, ss. 351]. [Artykuł recenzyjny]. „Czasopismo Prawno-Historyczne”, z. 2, s. 367-378.

25. Anna Stawarska-Rippel, ,Elementy prywatne $i$ publiczne $w$ procesie cywilnym $w$ świetle prac kodyfikacyjnych w Polsce (1918-1964). Studium historycznoprawne”, Katowice 2015, ss. 429. [Rec.]. „Czasopismo Prawno-Historyczne”, z. 1, s. $303-306$.

26. Piotr Fiedorczyk, „Prawo rodzinne $w$ pracach nad unifikacja i kodyfikacja prawa w Polsce (1945-1964)", Wydawnictwo Uniwersytetu w Białymstoku, Białystok 2014, ss. 811. [Rec.]. „Roczniki Administracji i Prawa”, [zeszyt specjalny], s. 545553.

27. Arkadiusz Bereza, „Sąd Najwyższy 1917-2017. Prezesi, sędziowie, prokuratorzy Sądu Najwyższego”. Wydawca: Sąd Najwyższy w Warszawie. Warszawa 2017, ss. 671. [Rec.]. „Roczniki Administracji i Prawa”, R. 17, z. 2, s. 385-390 [w języku angielskim], http://www.humanitas.edu.pl/pl/wydawnictwo/Czasopisma_naukowe /Roczniki_Administracji_i_Prawa\#tab_1297 [dostęp: 30.08.2019].

28. Kamil Niewiński, „PZPR a sadownictwo w latach 1980-1985. Próby powstrzymania »solidarnościowej« rewolucji”, Wydawnictwo Napoleon V, Oświęcim 2016. [Rec.]. „Roczniki Administracji i Prawa”, [zeszyt specjalny], s. 554-561.

29. Artur Korobowicz (1938-2017) - wspomnienie o Uczonym. „Roczniki Administracji i Prawa”, [zeszyt specjalny], s. 522-524.

30. Uczony, nauczyciel, przyjaciel. Stanisław Płaza zapisany w mojej pamięci. [wspomnienie]. „Krakowskie Studia z Historii Państwa i Prawa”; T. 10, z. 4, s. 648-657. 
31. GUŁag w systemie pracy ZSRR. W: Praca, jej rola i funkcje społeczne na przestrzeni wieków w kontekście Europy Środkowej. Red. A. Barciak. Katowice-Zabrze, Kultura Europy Środkowej T. 21, s. 328-348.

32. Rok 1917 i Estonii droga do pierwszej niepodległości. W setna rocznice rosyjskiej rewolucji. W: Ustrój państwa, myśl polityczno-prawna, wspótczesne systemy rzadów. Prace ofiarowane profesorowi zw. nauk prawnych Adamowi Jamrozowi z okazji Jego Jubileuszu. Red. S. Bożyk, A. Olechno. Białystok, s. 665-680.

33. Kodyfikacja prawa II Rzeczypospolitej. W: Oblicza Niepodległej. Red. W. Kalwat, A. Krok, A. Rodziewicz, M. Różański, K. Wichowska. Warszawa, s. 148-179.

34. Z dziejów organizowania Resortu Sprawiedliwości PKWN. Zagadnienia wybrane. W: Z historii ustroju i konstytucjonalizmu Polski. Księga jubileuszowa dedykowana w osiemdziesiata rocznice urodzin Profesora Mariana Kallasa. Red. D. Makiłła przy współpracy M. Wilczek-Karczewskiej. Warszawa, s. 453—471.

35. Komunizm a prawo (przypadek RSFRR i ZSRR). W: Rok 1917 w Rosji: carat rewolucja - nowa rzeczywistość. Red. B. Garczyk. „Poznańskie Studia Wschodnioznawcze" [Toruń], nr 13, s. 251-278.

36. Ziemia i praca, chtopi i kułacy w Rosji i ZSRR 1917-1941. W: Współczesne problemy prawa rolnego i cywilnego. Ksiega jubileuszowa Profesor Teresy Kurowskiej. Red. D. Łobos-Kotowska, P. Gala, M. Stańko. Warszawa, s. 279-298.

37. [Wspólnie z Wiktorem Hołubką]: Ukraina na drodze do niepodległości (19181920). W setna rocznice. „Miscellanea Historico-Iuridica”, T. 16, z. 1, s. 11-54.

38. Armenii droga do leninowsko-kemalowskiego rozbioru (1917-1921). „Czasopismo Prawno-Historyczne", T. 70, z. 1, s. 67-109.

39. «Юристы и революичя. Рго еt contra», авторы и составители С.М. Шахрай, К.П. Краковский, Московский государственный университет имени М.В. Ломоносова, Издательство »Кучково Поле«, Москва 2017, ss. 552. [Rec.]. „Czasopismo Prawno-Historyczne", T. 70, z. 2, s. 433-434.

40. Danuta Janicka: „Polska myśl prawnokarna XIX-XX wieku: autorzy i ich dzieła. Od szkoły klasycznej do socjologicznej”, posłowie J. Lachowski, Wyd. UMK, Toruń 2017, ss. 336. [Rec.]. „Czasopismo Prawno-Historyczne”, T. 70, z. 2, s. 428-432.

41. Tomasz Szczygiet, ,Wojskowe postepowanie karne w II Rzeczypospolitej (19181939)”, Wydawnictwo Uniwersytetu Ślaskiego, Katowice 2017, ss. 508. [Rec.]. „Czasopismo Prawno-Historyczne”, T. 70, z. 2, s. 411-419.

42. Komisja Kodyfikacyjna Drugiej Rzeczypospolitej. „Mówią Wieki”, [numer specjalny] 1 , s. $110-117$.

43. Gruzińska próba wybicia się na niepodległość. W stulecie proklamacji Demokratycznej Republiki Gruzji (1918). „Roczniki Administracji i Prawa”, R. 18, z. 1, s. $109-130$.

44. Słownik Biograficzny Adwokatów Polskich, A-Ż, tom 3: (zmarli w latach 19452010), zeszyt 1, wyd. Naczelna Rada Adwokacka, Redakcja „Palestry”, Warszawa 2018, ss. $662+X X X I V$. [Rec.]. „Roczniki Administracji i Prawa”, R. 18, z. 1, s. $445-448$. 
45. Historia zimnej wojny, t. I: Geneza, red. M. Leffler, O. A. Westad, ttum. M. Grzywa, Oświęcim 2017, ss. 536. [Tytuł oryginału: The Cambridge History of the Cold War, Volume I: Origins, Cambridge University Press 2010]. „Roczniki Administracji i Prawa" [Sosnowiec], R. 18, z. 2, s. 335-339; http://yadda.icm.edu.pl/yadda/ element/bwmeta1.element.polindex-article-orig-188429?q=bwmeta1.element. polindex-journal-issn-1644-9126-year-2018-volume-2-issue-XVIII;22\&qt=CHILD REN-STATELESS.

\section{9}

46. Anna Moszyńska: „,Geneza prawa spadkowego w polskim kodeksie cywilnym z 1964 roku", Wydawnictwo Naukowe Uniwersytetu Mikołaja Kopernika w Toruniu, Toruń 2019, ss. 672. [Rec.] „Roczniki Administracji i Prawa”, R. 19, z. 1, s. 407-412.

47. O rewolucyjnym wymiarze sprawiedliwości. Przykład komunistyczny. W: Rewolucje. Motywy-idee-ideologie. Zbiór studiów. Red. J. Farysej, G. Kucharczyk, K. Siemaszko. Gorzów Wielkopolski, s. 61-82.

48. [Wspólnie z Piotrem Fiedorczykiem, Anną Stawarską-Rippel]: Wojny XX wieku i ich skutki dla ustrojów państwowych i prawa. „Czasopismo Prawno-Historyczne", T. 71, z. 1, s. 57-100. 
